\title{
KOMASACIJA U FUNKCIJI POLJOZAŠTITNIH ŠUMSKIH POJASEVA U REPUBLICI SRBIJI - KRITIČKI OSVRT
}

\author{
LAND CONSOLIDATION IN THE FUNCTION OF SHELTERBELTS \\ FOR AGRICULTURAL LAND IN THE REPUBLIC OF SERBIA - CRTICAL \\ REVIEW
}

\author{
Goran MARINKOVIĆ ${ }^{1}$, Ilija GRGIĆ2, Jelena LAZIĆ ${ }^{3}$, Milan TRIFKOVIĆ4
}

\begin{abstract}
SAŽETAK
U ovome radu prikazani su rezultati analize realizacije poljozaštitnih šumskih pojaseva u postupku komasacije. Istraživanjem su obuhvaćena tri karakteristična projekta komasacije u Autonomnoj pokrajini Vojvodini, kroz čije provođenje je trebalo realizirati i projekte poljozaštitnih šumskih pojaseva. S obzirom da se izabrani projekti nalaze u različitim dijelovima područja istraživanja, zaključci izvedeni u ovome radu mogu se smatrati reprezentativnim za teritorij Vojvodine. Studija je pokazala da nije iskorištena prilika za povećanjem šumovitosti Vojvodine, odnosno da projekti poljozaštitnih šumskih pojaseva nisu uopće razmatrani u postupku komasacije ili ako su i uzimani u obzir, zemljište odvojeno za njih nikad nije privedeno namjeni.
\end{abstract}

KLJUČNE RIJEČl: eolska erozija, poljozaštitni šumski pojasevi, komasacija

\section{UVOD}

\section{INTRODUCTION}

Šume i šumsko zemljište mogu se smatrati neophodnim uvjetom za opstanak ljudskog društva u cjelini. Osim toga šume imaju i velik ekonomski i ekološki značaj (Drekić i sur., 2016). Šume imaju važnu ulogu u prevenciji nastajanja bujica i erozije zemljišta, najbolji su i najjeftiniji filter pitke vode, veliki proizvođači kisika i filter zagađene atmosfere, smanjuju buku itd. Postoji velik broj članaka u kojima se na različite načine ističe važnost šuma. Domac i suradnici (2015) u svome radu analiziraju da li postojanje šuma i proizvodnja biomase može pokrenuti energijsku tranziciju u Hrvatskoj i zemljama Jugoistočne Europe. U članku (Martinić, 2004) se šumarska struka i javnost upoznaju s važnošću i ulogom šuma i ekološke mreže kao najznačajnijeg globalnog instrumenta u zaštiti i očuvanju ugroženih vrsta i staništa. Domec (2000) navodi brojne pozitivne socijalnoekonomske učinke postojanja šuma i proizvodnje energije iz biomase, kao njenog direktnog proizvoda. Krpina i suradnici (2014) u svom članku pozornost usmjeravaju na turističko-rekreativnu funkciju šuma kao sastavni dio opće korisnih funkcija šuma, koje svojim položajem, izgledom ili nekim drugim funkcijama povećavaju turistički promet.

Šume imaju signifikantnu ulogu u smanjenju štetnih posljedica eolske erozije kako u poljoprivredi, tako i u vodoprivredi, ali i mnogim sferama ljudskih aktivnosti. Eolska erozija nastaje kao rezultat međusobnih odnosa klime, geološko-pedološke podloge, reljefa i načina iskorištavanja

\footnotetext{
${ }^{1}$ Doc. dr. Goran Marinković, dipl. ing. geod., Fakultet tehničkih nauka Novi Sad, e-mail: goranmarinkovic@uns.ac.rs

${ }^{2}$ Dr. sc. llija Grgić, Državna geodetska uprava, Zagreb, Hrvatska, e-mail: ilija.grgic@dgu.hr

${ }^{3}$ Jelena Lazić, mast. ing. geod., Fakultet tehničkih nauka Novi Sad, e-mail: lazicjelena@uns.ac.rs

${ }^{4}$ Prof. dr. Milan Trifković, dipl. ing. geod., Građevinski fakultet Subotica, e-mail: milantri@eunet.rs
} 
zemljišta. S obzirom na to, može se zaključiti da je u velikoj mjeri prisutna, a posebice u ravničarskim predjelima gdje je osnovna privredna grana poljoprivreda. Ako se tome doda da je, posebno na teritoriju Vojvodine, zemljište uslijed intenzivnog korištenja erodibilnije, a klima izuzetno suha, može se reći da su svi uvjeti za maksimalno djelovanje eolske erozije ispunjeni (Lukić, 2005).

Uz sve značajne pozitivne utjecaje šuma na poljoprivredu, ni Strategija razvoja šumarstva Republike Srbije (2006), niti Strategija poljoprivrede i ruralnog razvoja Republike Srbije za period 2014.-2024. godine (2014) ne prepoznaju značenje i ulogu poljozaštitnih šumskih pojaseva i njihov ogroman doprinos poljoprivredi. Poljozaštitni šumski pojasevi se u Strategiji razvoja šumarstva ne spominju uopće, dok se u Strategiji poljoprivrede i ruralnog razvoja Republike Srbije za period 2014.-2024. godine, spominju samo jednom. Bez obzira na činjenicu da stručni i znanstveni radovi iz domaće i svjetske literature već dugi niz godina ovu temu ističu kao izuzetno značajnu, ona nije na odgovarajući način artikulirana i operacionalizirana kroz fundamentalne dokumente Republike Srbije, koji trebaju biti osnova za svakodnevnu praksu. Zanemarivanje ove značajne teme u fundamentalnim strateškim dokumentima, može biti jedan od uzroka izostanka adekvatnog uspostavljanja poljozaštitnih šumskih pojaseva u komasacijskim projektima. Zakon o šumama Republike Srbije (2015) također ne prepoznaje pojam poljozaštitnih šumskih pojaseva, kao ni Zakon o poljoprivredi i ruralnom razvoju (2016) i Zakon o poljoprivrednom zemljištu (2017).

Istraživanje provedeno u ovome radu koje se odnosi na neposvećivanje dovoljne pozornosti formiranju poljozaštitnih šumskih pojaseva, nije utvrdilo egzaktne razloge za ovakvu situaciju. Pojedina saznanja autora, zasnovana na osobnom iskustvu i učešću u stručnim diskusijama, ukazuju da razlozi mogu biti različiti i teško sagledivi. Zapostavljanje teme poljozaštitnih šumskih pojaseva u strateškim dokumentima i njen tretman koji nije odgovarajući njenom značenju, potencijalna je posljedica izostanka uključenja multidisciplinarnih znanja u timovima koji izrađuju strateške dokumente. Naime, za autore navedenih dokumenata, suštinski i strateški problemi šumarstva nisu poljoprivredna pitanja i obrnuto, strateški problemi iz područja poljoprivrede nisu pitanja iz područja šumarstva. Međutim, imajući u vidu citiranu stručnu literaturu, simbioza znanja iz područja šumarstva i poljoprivrede, primijenjenih na uspostavu poljozaštitnih šumskih pojaseva, značajno doprinosi razvoju i poljoprivrede i šumarstva. Maksimiziranje doprinosa poljozaštitnih šumskih pojaseva poljoprivrednim kulturama (bilo da se radi o poljoprivrednim prinosima ili visini bazičnih ulaganja u poljoprivredu) zahtijeva multidisciplinarni pristup, pri čemu i poljoprivredni i šumarski stručnjaci imaju isti cilj - povećanje performansi poljoprivredne proizvodnje. Povećanje per- formansi poljoprivredne proizvodnje, prema mišljenju autora, ima cilj koji mora ispuniti bar neke od sljedećih uvjeta: da maksimizira poljoprivrednu proizvodnju, da smanji ukupna ulaganja, da održi i unaprijedi razinu kvalitete zemljišta i osigura optimalne mikroklimatske uvjete za razvoj poljoprivrednih kultura.

Drugi potencijalni razlog za izostanak intenzivnijeg bavljenja ovim pitanjem može biti neadekvatna metodologija definiranja prioriteta na državnoj razini. Gubici koji uslijed izostavljanja poljozaštitnih šumskih pojaseva nastaju u poljoprivredi, očigledno se ne smatraju značajnim, na što ukazuje činjenica da u stručnoj literaturi u Srbiji nisu pronađeni radovi koji se detaljno bave ovakvim analizama, kao što je to slučaj u nekim europskim zemljama (npr. Velika Britanija, Njemačka, Mađarska, Švicarska i Rusija, (Caborn, 1957)).

Treći potencijalni razlog zanemarivanja šire znanstvene diskusije o poljozaštitnim šumskim pojasevima, ogleda se $u$ težnji da se maksimizira značaj drugih pitanja kao što su primjena agrotehnike s ciljem povećanja produktivnosti i ekonomskih efekata poljoprivredne proizvodnje, pri čemu se ulaganja minimiziraju. Uspostava poljozaštitnih šumskih pojaseva zahtijeva angažman eksperata šumarske i poljoprivredne struke, i iziskuje dodatne troškove za koje investitori nisu zainteresirani. Neprepoznavanje značenja poljozaštitnih šumskih pojaseva i njihova nedovoljna implementacija, nije međutim karakteristična samo za Srbiju. Sveobuhvatno istraživanje o poljozaštitnim šumskim pojasevima u Kanadi (Rempel i sur., 2016) rezultiralo je zaključkom da, u okviru svojih upravljačkih odluka, većina proizvođača ne prepoznaje koristi od poljozaštitnih šumskih pojaseva, zato što oni nemaju kompenzaciju za dobitke koji na taj način osiguravaju za društvo u cjelini. Treba naglasiti da je navedeno istraživanje provedeno metodom anketiranja, na osnovi kojeg je izveden zaključak iz perspektive proizvođača, što znači da u analizi ekonomske kategorije nisu uzete u obzir. Ekonomska analiza (Brandle i sur., 1992) pokazuje da neto sadašnja vrijednost ulaganja u poljozaštitne šumske pojaseve ostaje pozitivna čak i pri diskontnoj stopi od 11\%. „Kost-benefit“ analiza je, (Jones i Sudmeyer, 2002) kada se gleda scenarij sa i bez poljozaštitnih šumskih pojaseva, pokazala povećanje profitabilnosti u slučaju kada oni štite usjeve od oštećenja izazvanog vjetrom. Analiziranjem samo tri navedena rada, očigledan je zaključak da ekonomske koristi od poljozaštitnih šumskih pojaseva u poljoprivredi, koje sigurno postoje, mogu biti poništene subjektivnim stavom poljoprivrednika da oni time doprinose više društvu nego svojim ciljevima (zaštiti usjeva i povećanju profita). Imajući $\mathrm{u}$ vidu da se navedeni primjeri odnose na visoko razvijene zemlje koje raspolažu značajnim sredstvima za ulaganja u poljoprivredu i zaštitu životne sredine, može se naći izvjesno opravdanje za stanje u ovom području u manje razvijenim zemljama. Međutim, autori ovoga rada smatraju 
da unapređenje poljoprivredne proizvodnje i njene profitabilnosti trebaju biti prilika za manje razvijene države da pravilnim ulaganjem u poljoprivredu i praktičnom primjenom multidisciplinarnog znanja iz područja poljoprivrede, šumarstva i zaštite životne sredine, postignu sinergijski efekt i smanje zaostatak u ekonomskom razvoju. Sinergijski efekt u navedenom smislu podrazumijeva da se pravilnim kombiniranjem znanja iz područja poljoprivrede, šumarstva i zaštite životne sredine, postignu veće koristi za jedno društvo nego što bi se to postiglo primjenom pojedinačnih znanja.

Sinergijski efekt ekspertnih znanja rezultira održivim razvojem, koji prema Ujedinjenim Narodima predstavlja pravo sadašnje generacije na razvoj bez ugrožavanja tog prava budućim generacijama. Prema (Pearce i sur., 1990), s ekonomskog gledišta održivi razvoj se definira na sljedeći način: „Razvoj strategije za upravljanje imovinom, prirodnim i ljudskim resursima, kao i financijskom i fizičkom imovinom za dugoročno uvećanje bogatstva zajednice. Održivi razvoj kao cilj odbacuje politike i prakse koje podržavaju održavanje tekućeg standarda života, zasnovane na iscrpljivanju produktivne baze, uključujući prirodne resurse i ostavljajući budućim generacijama siromašniju perspektivu i veće rizike od sadašnjih“. Ukoliko se navedena ekonomska definicija prihvati kao polazna osnova i primijeni na poljoprivredno zemljište kao resurs, onda neposredno slijedi da su neprihvatljive sve strategije koje za posljedicu imaju iscrpljivanje produktivne baze i ostavljaju budućim generacijama siromašniju perspektivu. Sa stajališta ove polazne pretpostavke neposredno slijedi da se svaka strategija i svaki konkretni projekt koji utječe na određene prirodne resurse mora ocijeniti s aspekta procijenjenih utjecaja na produktivnu bazu, odnosno na njeno stanje u kome će se ona naći nakon primjene strategije. Aspstraktno promatrano, može se s visokom razinom sigurnosti zaključiti da će zemljište kao resurs biti u većoj mjeri devastirano ako se ne izvrši njegova odgovarajuća zaštita, odnosno da će zemljište bez poljozaštitnih šumskih pojaseva, biti izloženo većem iscrpljivanju nego uz njih. Načelo održivog razvoja sugerira da se moraju uzeti u obzir svi čimbenici utjecaja na promatrani prirodni resurs i da se korištenje tog resursa mora razmatrati iz različitih perspektiva. $U$ ovom radu krenulo se od pretpostavke da samo uz adekvatnu kombinaciju ekspertskih znanja iz područja šumarstva, poljoprivrede i zaštite životne sredine, postoji mogućnost ostvarivanja ciljeva održivog razvoja u području poljoprivrede.

Komasacijom i arondacijom poljoprivrednih parcela, male površine pod sustavima za navodnjavanje, izmijenjena struktura sjetve, kao i višegodišnje ekstremno sušni periodi, samo su neki od čimbenika koji ukazuju da je potencijalna ugroženost Vojvodine eolskom erozijom zaista velika, a da uz eventualnu realizaciju prognoziranih klimatskih promjena može još više doći do izražaja (Letić i Savić, 2006).
Istraživanja u Europi pokazuju da eolska erozija ugrožava oko 42.000.000 hektara poljoprivrednog zemljišta (Letić i Savić, 2006).

Najbolja zaštita poljoprivrednog zemljišta od eolske erozije je podizanje poljozaštitnih šumskih pojaseva, koji bi s obzirom na nisku šumovitost Vojvodine, osim značajne uloge u poboljšanju poljoprivredne proizvodnje, imali i veliko značenje i za održivost društvene zajednice uopće.

Poljozaštitni šumski pojasevi postavljaju se planski, u vidu mreže koja pokriva dio teritorija, sopćim ciljem djelovanja na vjetar u tolikoj mjeri da modificiraju njegovo djelovanje prema posebnim zahtjevima. Na parcelama koje se koriste za poljoprivrednu proizvodnju, njihovo djelovanje je usmjereno na stabilnost prinosa kultura u međuprostoru. To su, dakle, linijski objekti koji se sastoje od jednog ili više redova drveća i grmlja i predstavljaju barijeru vjetru. Postavljaju se uspravno ili što uspravnije na smjer dominantnog vjetra i to najčešće u dva smjera (tako nastaju glavni i sporedni pojasevi), jer samo u tom slučaju pokazuju optimalno djelovanje na redukciju brzine vjetra (Lukić, 2005).

Šumski poljozaštitni pojasevi kao biološki oblik borbe protiv eolske erozije i neproduktivnog isparavanja, već drugi niz godina postoje u raznim dijelovima svijeta (Dožić, 2006).

Kada se govori o poljozaštitnim šumskim pojasevima, posebno je važno odabrati vrstu drveća koje brzo raste i koje će u najkraćem roku imati funkciju zbog koje se i sadi. Važnost postojanja pojedinih vrsta drveta u posavskim nizinskim šumama zbog brzine rasta i kratke ophodnje, naglašena je u radu (Drvodelić i Oršanić, 2016), što bi svakako trebalo iskoristiti i kod podizanja poljozaštitnih šumskih pojaseva.

Kod projektiranja poljozaštitnih šumskih pojaseva, velik problem (ponekad čak i nepremostivu prepreku) predstavlja osiguranje zemljišta za realizaciju projekata. Najjednostavnije rješenje je realizacija ovakvih projekata kroz postupke komasacije. Naime, u postupku komasacije se obavezno izrađuje projekt putne i kanalske mreže (veoma često samo putne mreže, a naziva se projekt putne i kanalske mreže), gdje se zemljište za nijhovu izgradnju osigurava iz fonda zemljišta za zajedničke potrebe, koje se proporcionalno uzima od svakog sudionika komasacije. S obzirom da se ovaj projekt izrađuje s ciljem formiranja pravilnih zemljišnih površina i okrupnjavanja parcela, jasno je da bi se i projekti poljozaštitnih šumskih pojaseva morali izrađivati paralelno s njima. Razmotri li se praksa realizacije komasacijskih projekata u Republici Srbiji (893 realizirana projekta komasacije), dolazi se do zaključka da do 2011. godine, niti u jednom komasacijskom projektu nisu razmatrani poljozaštitni šumski pojasevi. Ova činjenica ukazuje na to da je propuštena prilika za optimalnim uređenjem terena i poljoprivrednog zemljišta, uz jednostavno osiguranje zemljišnih površina za zajedničke namjene. 
Zbog negativnih utjecaja eolske erozije, poljozaštitni šumski pojasevi su mjestimično podizani, ali ne kroz postupak komasacije. U takvim slučajevima, njihovo podizanje jedino je bilo moguće na državnom ili društvenom zemljištu (ne tamo gdje je potrebno, nego tamo gdje je moguće). To je dovelo do toga da njihova osnovna funkcija zaštite poljoprivrednog zemljišta od eolske erozije bude samo djelomično ispunjena, odnosno štitili su samo zemljište gdje su bili postavljeni, a ne svo ono zemljište kojemu je zaštita bila realno potrebna.

Upravo iz tog razloga predmet istraživanja ovoga rada predstavljaju projekti poljozaštitnih šumskih pojaseva i njihova veza s komasacijom, s ciljem da se utvrdi u kojoj mjeri su realizirani na terenu, u situaciji kada su realizirani komasacijski projekti, odnosno da li postoji odstupanje između definiranih i realiziranih projekata poljozaštitnih šumskih pojaseva.

Istraživanje je provedeno na teritoriju Vojvodine, pri čemu je prikazano stanje u karakterističnim općinama Bečej, Sombor i Vršac. Kao rezultat istraživanja, prikazano je neslaganje između realiziranog stanja na terenu i definiranih i projektom predviđenih poljozaštitnih pojaseva.

\section{MATERIJALI I METODE MATERIALS AND METHODS}

Osnovni materijal za istraživanja u ovom radu predstavljaju projekti komasacije u Vojvodini. Vojvodina kao geografsko područje predstavlja značajan izvor za istraživanje iz područja očuvanja poljoprivrednog zemljišta kao najvrjednijeg resursa, zbog izraženosti dva ekstrema:

- Potreba za maksimiziranjem iskorištenosti kvalitetnog poljoprivrednog zemljišta; i

- Niska šumovitost koja ugrožava održivi razvoj poljoprivrede, kroz smanjenje performansi poljoprivredne proizvodnje na duži rok.

Autori ovog teksta su mišljenja da je proces komasacije, kojim se predviđa i podizanje poljozaštitnih šumskih pojaseva, najbolje sredstvo za optimizaciju dva konfliktna cilja: maksimiziranje iskorištenosti poljoprivrednog zemljišta i težnje da se njegove karakteristike za poljoprivrednu proizvodnju očuvaju u što dužem razdoblju.

Metode istraživanja suglasne su s postavljenim ciljevima i zasnivaju se na teorijskim istraživanjima aktualne stručne literature i svjetskih iskustava, kao i uspoređivanjem projekata komasacije, uz očuvanje načela da je neophodno predvidjeti uspostavljanje poljozaštitnih šumskih pojaseva. Ukoliko poljozaštitni šumski pojasevi nisu predviđeni projektom, zaključuje se njihova potpuna odsustnost, dok se u slučaju projektiranih poljozaštitnih šumskih pojaseva vrši uspoređivanje projektiranog i činjeničnog stanja na terenu. Ostali podaci od važnosti za analizu stanja dobiveni su na osnovi službenih statistika i iz znanstvene literature.
Područje istraživanja obuhvatilo je karakteristične dostupne projekte u Vojvodini, iz razloga što se projekti komasacije najviše i najčešće realiziraju na ravničarskim zemljištima, koja su s gledišta poljoprivrede najvrednija, uz istovremeno uvažavanje krovnih dokumenata koji se odnose na cjelokupni teritorij Republike Srbije.

\section{PROCJENA OPTIMALNE ŠUMOVITOSTI U VOJVODINI ESTIMATION OF OPTIMAL FOREST IN VOJVODINA}

Optimalna površina pod šumom i zaštitnim nasadima procijenjena je na osnovi postavljenoga cilja osiguranja prosječne površine šuma i zaštitnog zelenila na razini od 0,16 ha po stanovniku, čime bi se približili standardima razvijenih zemalja u Europi. Prema tome, šume bi u Vojvodini trebale zauzimati površinu od 308.045 ha, tako da bi u tom slučaju šumovitost Vojvodine sa sadašnjih $6,37 \%$ bila povećana, odnosno podignuta na 14,32\% (Vojvodinašume, 2018).

Struktura ovako podignute šumovitosti bila bi (Vojvodinašume, 2018):

- Površina šuma 193.621 ha;

- Površina zaštitnih nasada u poljoprivredi 84.196 ha;

- Zaštitni nasadi u vodoprivredi 4.147 ha;

- Zaštitni nasadi uz prometnice 4.426 ha;

- Zaštitno zelenilo u naseljima 21.055 ha.

Prethodno navedeni podaci ukazuju na esencijalnu ugroženost područja Vojvodine, jer sveukupna pošumljenost predstavlja tek oko $46 \%$ od predviđene optimalne šumovitosti.

Stanje je još katastrofalnije kada se zna da su danas šumski nasadi gotovo isključivo svedeni i ograničeni na uske lokalitete uzduž riječnih tokova, zatim na pribrježja i brdske predjele Fruške gore i Vršačkog brijega. Na tim prostorima se nalazi oko $90 \%$ površina šuma i zaštitnih nasada, a samo oko $10 \%$ površina disperzirano je po poljima Vojvodine. Ako se ovim malim površinama šuma, disperziranim po vojvođanskim poljima, doda oko $11.600 \mathrm{~km}$ zelenih drvoreda, onda stvarna obraslost vojvođanskih polja iznosi svega oko $1,5 \%$ od ukupne poljoprivredne površine. Ovo jasno govori da je šumovitost Vojvodine izrazito mala, zbog čega je područje u značajnoj mjeri izloženo eolskoj eroziji.

\section{IZGRADNJA POLJOZAŠTITNIH ŠUMSKIH POJASEVA U POSTUPKU KOMASACIJE SHELTERBELTS BULDING DURING THE LAND CONSOLIDATION PROCESS}

Prema (Marinković i sur., 2013) komasacija zemljišta je jedna od mjera u području agrara kojoj je svrha omogućiti 
ekonomičniju i racionalniju proizvodnju i riješiti niz drugih problema vezanih za poljoprivredu, uređenje naselja, infrastrukturne projekte i zaštitu životne sredine. Komasacija zemljišta predstavlja ne samo instrument prostornog uređenja, već proces koji zahvaća sve probleme vezane za suvremeno uređenje određenog područja, pa i šumarstvo.

Prilikom provođenja komasacije u Republici Srbiji šumama se ne posvećuje pozornost, samim tim ne postoji ni svijest o važnosti podizanja poljozaštitnih šumskih pojaseva. $\mathrm{Na}$ području bivše SFRJ jedino su zakonski propisi o komasaciji Slovenije i Hrvatske uključivali i šume u komasaciju.

Po najnovijem Zakonu o poljoprivrednome zemljištu Republike Srbije (2017), kojim je i regulirana komasacija u Srbiji, kaže se da su "... predmet komasacije sva zemljišta u komasacijskom području. Kada skupština općine ocijeni da postoje opravdani razlozi, pojedina zemljišta (voćnjaci, vinogradi, šume) mogu se izuzeti iz komasacijske mase".

Razmatranjem ove odredbe zakona, može se steći dojam da se šume i šumsko zemljište uključuju u komasaciju, ali naprotiv, vrlo često se koristi odredba zakona kojom se šume i višegodišnji nasadi isključuju iz postupka komasacije.

Nedostatna pošumljenost Vojvodine bi se donekle mogla riješiti kroz postupak komasacije. Naime, osiguranje površina za zajedničke potrebe, pa samim tim i za poljozaštitne šumske pojaseve, ostvaruje se kroz učešće svih sudionika komasacije u njima, što svakako olakšava postupak. Prema tome, komasacija zemljišta predstavlja koristan alat i za zahtjevne infrastrukturne projekte (Hendricks i Lisec, 2014), najčešće kroz osiguranje zemljišta za zajedničke potrebe i prevenciju daljnjeg usitnjavanja posjeda. Projekti iz područja regulacije vodnog režima, izgradnje infrastrukture i šumarstva u Vojvodini, najlakše i najjednostavnije se mogu realizirati kroz provođenje procesa komasacije (Trifković i sur., 2016).

Kako je cilj ovog rada utvrđivanje postojanja odstupanja između definiranih projekata poljozaštitnih šumskih pojaseva i realiziranog stanja na terenu, u radu će za odabrane karakteristične pojaseve u općinama Bečej, Sombor i Vršac, biti prikazano projektno rešenje, a zatim i zatečeno stanje na terenu.

\section{Projekt poljozaštitnih šumskih pojaseva na području Općine Bečej - The design of shelterbelts on the area of Bečej municipality}

Nositelj ovog projekta je Šumarski fakultet iz Beograda, katedra za melioraciju.

Kako je navedeno u projektu, općina Bečej, prema Prostornom planu tadašnje Socijalističke Autonomne Pokrajine Vojvodine (SAPV), spadala je u područja s najmanjom šumovitošću (prva zona), koja se kreće od 0,3-3,0 \%, a pla- nom do 2000. godine predviđeno je da će se postići šumovitost od $6 \%$, što naravno nije učinjeno.

Također, Zakonom o komasaciji i arondaciji SAPV predviđeno je da se projekti komasacije i podizanje šumskih zaštitnih pojaseva rade paralelno. Međutim, komasacija je u Općini Bečej rađena sedamdesetih godina, a Projekt šumskih zaštitnih pojaseva za tu općinu je iz 1984. godine, što jasno ukazuje na odstupanje od ovog postulata.

Projektom je također ukazano na dvije moguće opcije kojima se pristupa ukoliko se žele izbjeći ili nadići problemi poput postavljanja pojaseva na manje povoljan način, zbog npr. skretanja granice pojasa i ukoliko bi to iziskivalo zauzimanje tuđih zemljišnih površina, odnosno površina koje su privatne ili pripadaju drugom ataru. Te dvije opcije su (ŠFB, 1984):

- Postizanje dogovora (sporazuma) o postavljanju pojaseva na tim površinama (s osobama koje su vlasnici i korisnici); i

- Svjesno ići na eksproprijaciju.

Prilikom istraživanja, došlo se do podataka da su realizirani samo oni pojasevi koji se nalaze na zemljištu Poljoprivrednog kombinata PIK Bečej, koje je u to vrijeme bilo društveno, odnosno da su se svjesno izbjegavali privatni posjedi i eksproprijacija.

Podaci o komasaciji koja je rađena sedamdesetih godina nisu pronađeni u Službi za katastar nekretnina u Bečeju, jer su prema riječima nadležnih tijela, podaci uništeni prilikom jedne nezgode $\mathrm{u}$ arhivi te ustanove.

U nastavku teksta slijedi analiza nekoliko karakterističnih projektiranih i realiziranih poljozaštitnih šumskih pojaseva u Općini Bečej.

\section{Poljozaštitni šumski pojasevi P5 i P6 - Protective forest belts P5 and P6}

Pojas P-5 nalazi se na dijelu bečejskog atara prema katastarskoj općini Radičević i ima karakteristike glavnog pojasa. Dužina samog pojasa iznosi 1.550 m, s 10.670 sadnica u pet redova (ŠFB, 1984).

Poljozaštitni šumski pojas P6 se također nalazi na dijelu bečejskog atara, čija ukupna dužina prema projektu iznosi 10.485 m, s 20.970 sadnica u pet redova (ŠFB, 1984).

Projektno rješenje pojaseva P5 i P6, dano je na slici 1.

Obilaskom terena, utvrđeno je da pojas P-5 na projektiranoj lokaciji postoji samo na jednom dijelu i to na dužini od oko 2.000 metara. Visina stabala je oko $15 \mathrm{~m}$, razmak između stabala oko 3 metra. Prema projektu, pojas sadrži dva reda bagrema i tri reda javora. Međutim, na terenu je uočen pojas koji čini samo jedan red i to sibirskog brijesta (vrste koja je inače i najzastupljenija na ovom području). Stanje i pozicija pojasa $\mathrm{P} 5$ na terenu je prikazani na slici 2. 


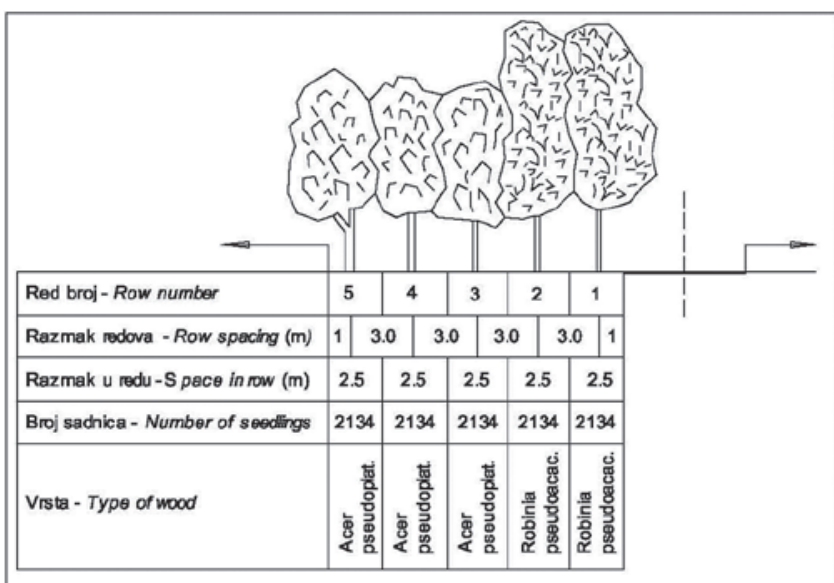

Slika 1. Prikaz presjeka pojasa P-5 (lijevo) i pojasa P-6 (desno)

Figure 1. Reperesentation of shelterbelts P-5 (left) and P6 (right)

Za pojas P-6 je utvrđeno da na projektiranoj lokaciji uopće i ne postoji (slika 3 ).

Detaljnim pregledom svih lokacija gdje je projektom predviđeno podizanje poljozaštitnih šumskih pojaseva, može se
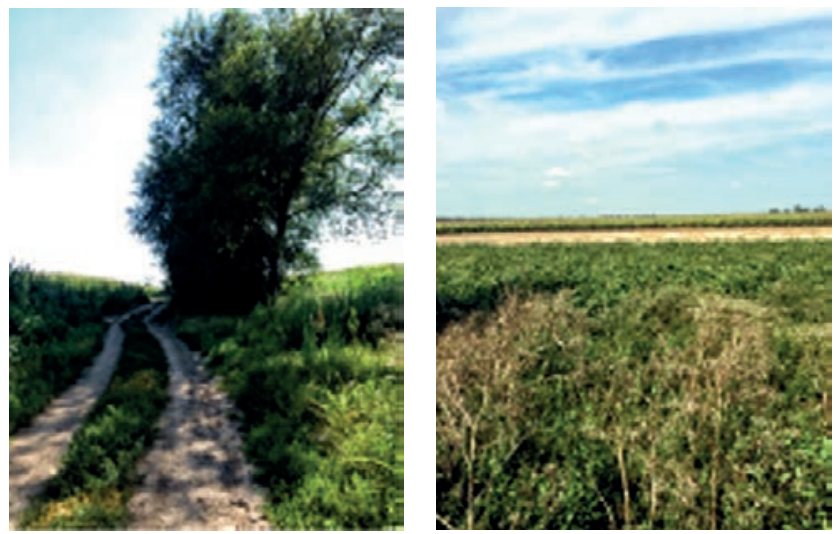

Slika 2. Prikaz terena gdje je projektom predviđen pojas P-5 Figure 2. Representation of area where the shelterbelt P-5 was foreseen by project
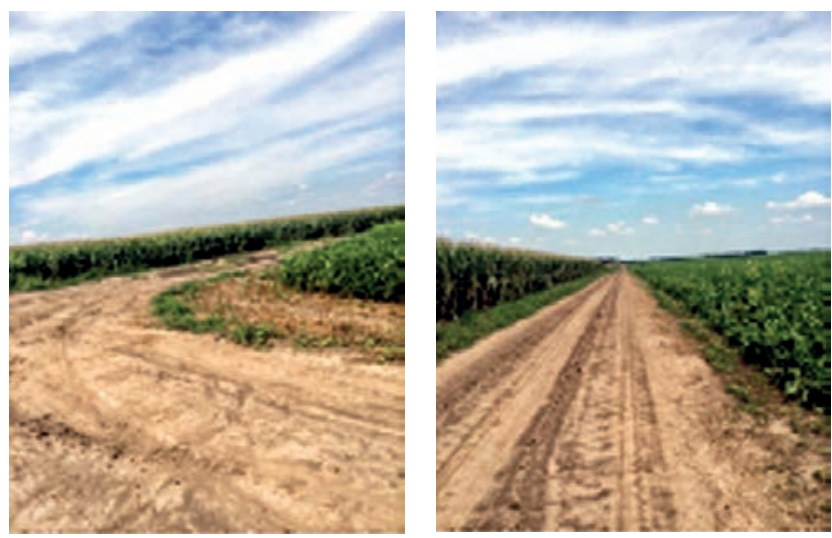

Slika 3. Prikaz terena gdje je projektom predviđen pojas P-6

Figure 3. Representation of area where the shelterbelt P-6 was foreseen by project

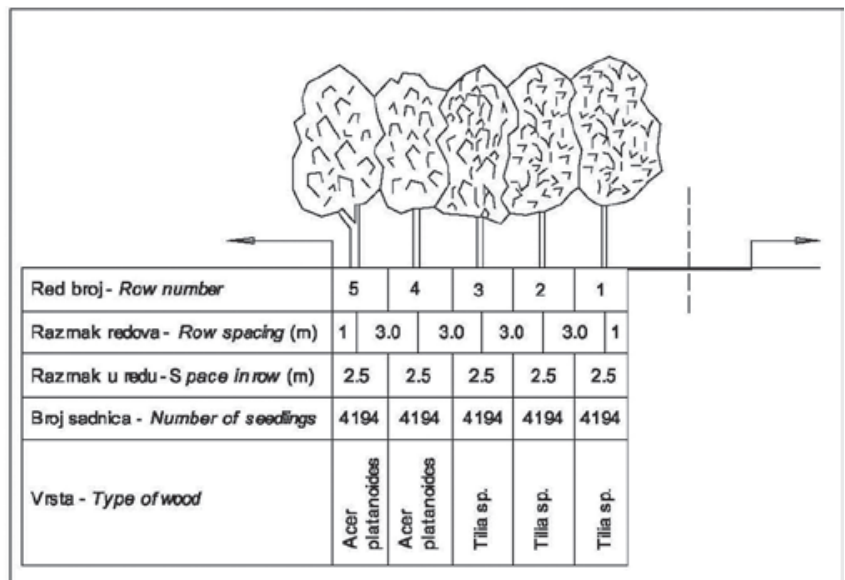

zaključiti da su oni podignuti na svega $10 \%$ površine, pri čemu niti jedan nije podignut sukladno projektu.

Projekt poljozaštitnih šumskih pojaseva na području Općine Sombor - The design of shelterbelts on the area of Sombor municipality

Nositelj ovog projekta je takođe Šumarski fakultet iz Beograda, katedra za melioraciju.

Prilikom istraživanja došlo se do zaključka da projekat poljozaštitnih pojaseva (izrađen 1989. godine) nije ušao u projekt komasacije (realizirana devedesetih godina), iako su ova dva projekta trebala biti realizirana istovremeno. Međutim, mali broj pojaseva je podignut, ali na dijelovima tabli društvenog zemljišta, a ne na parcelama koje su u postupku komasacije u tu svrhu trebale biti izdvojene (što se može vidjeti i na ažurnim planovima).

Slijedi pregled nekoliko karakterističnih šumskih pojaseva u Općini Sombor.

\section{Poljozaštitni šumski pojasevi uz asfaltne ceste AS-1 i AS-6 - Shelterbelts near asphalt roads AS-1 and AS-6}

Asfaltna cesta AS- 1 vodi od ceste Sombor-Stapar do Čičova, iza prelaska preko Velikog kanala. Ukupna dužina ceste iznosi $1.700 \mathrm{~m}$.

Zaštitni pojas kraj asfaltne ceste AS-1 projektiran je s južne strane asfaltne ceste u dužini od $1.700 \mathrm{~m}$ i ima dva reda topole s 1.134 sadnice (ŠFB, 1989) (Slika 4 - lijevo).

Na predmetnoj lokaciji utvrđeno je da postoji nekadašnji drvored jablana, koji je sada prorijeđen, kao i izdanci bagrema koji ukazuju da je nekada na tom dijelu bio posađen. Međutim, danas to uslijed neodržavanja ima izgled prilično neuglednog niskog raslinja. S južne strane puta, projektom je predviđeno dva reda topole, koji nisu posađeni (Slika 4 - desno). 

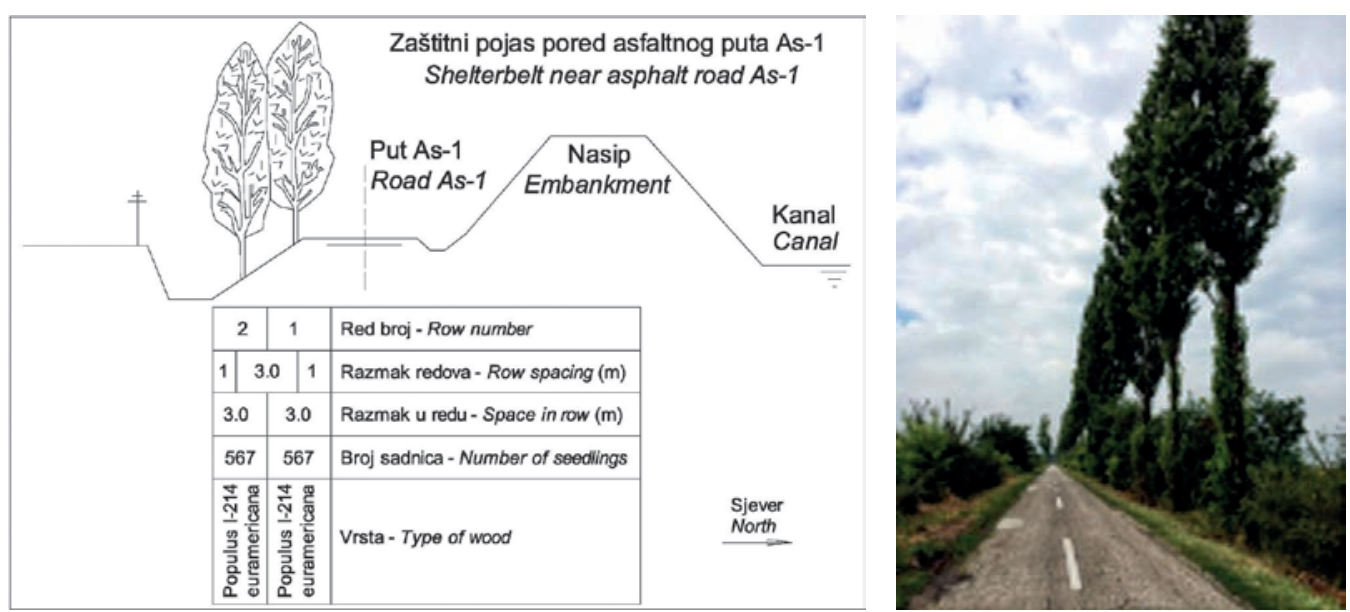

Slika 4. Zaštitni pojas kraj asfaltne ceste AS-1 - projektno rješenje (lijevo), stanje na terenu (desno)

Figure 4. Shelterbelt near asphalt road AS-1 - project solution (left) and the state on the terrain (right)

Asfaltni put AS-6 dug je 1.780 metara i nalazi se na oko 4,2 $\mathrm{km}$ prije Bezdana, kada se ide iz smjera Sombora. Projektom je predviđeno da pojas bude postavljen $s$ južne strane puta i da ima dva reda virginijske borovice (porodica čempresova), ažurne strukture s 1.188 sadnica (ك̌FB, 1989) (slika 5 - lijevo).

Prilikom obilaska terena uočeno je da uz asfaltnu cestu AS6, definitivno postoji pojas s jedne strane puta i to cijelom dužinom do ekonomije „Bezdan“. Međutim, ne radi se o čempresima, tj. virginijskoj borovici kako je projektom predviđeno, već se radi o bagremu i topoli u prilično nejasnoj strukturi, jer se pojas očigledno ne održava (slika 5 desno).

Detaljnim pregledom svih lokacija gdje je projektom predviđeno podizanje poljozaštitnih šumskih pojaseva, može se zaključiti da je situacija nešto malo bolja nego u Bečeju. Pojasevi su podignuti na oko $15 \%$ površine, pri čemu kao i u Bečeju, niti jedan nije podignut prema projektu.

\section{Projekt poljozaštitnih šumskih pojaseva za područje} Općine Vršac - The design of shelterbelts on the area of Vršac municipality

Glavni projekt poljozaštitnih šumskih pojaseva za područje Općine Vršac izrađen je 2003. godine i predstavlja jedan od rijetkih primjera u Republici Srbiji, gdje su šumski pojasevi uključeni u komasaciju. Projekt je izradio Šumarski fakultet iz Beograda.

U projektu je navedeno da na području Općine Vršac nisu vršena posebna istraživanja intenziteta eolske erozije, ali da je na osnovi istraživanja koja su vršena na drugim lokacijama u Vojvodini, utvrđena potreba za zaštitom od štetnog utjecaja vjetra, na razini koja iziskuje žurna rješenja. Samim time, u svim katastarskim općinama, tip planiranog pojasa je određen kao glavni tip s pet redova sadnica, na pravilnoj udaljenosti od po 3 metra.

Poljozaštitni pojasevi su projektirani za cijeli teritorij općine Vršac, a prihvaćeno je da se udaljenosti između pojaseva
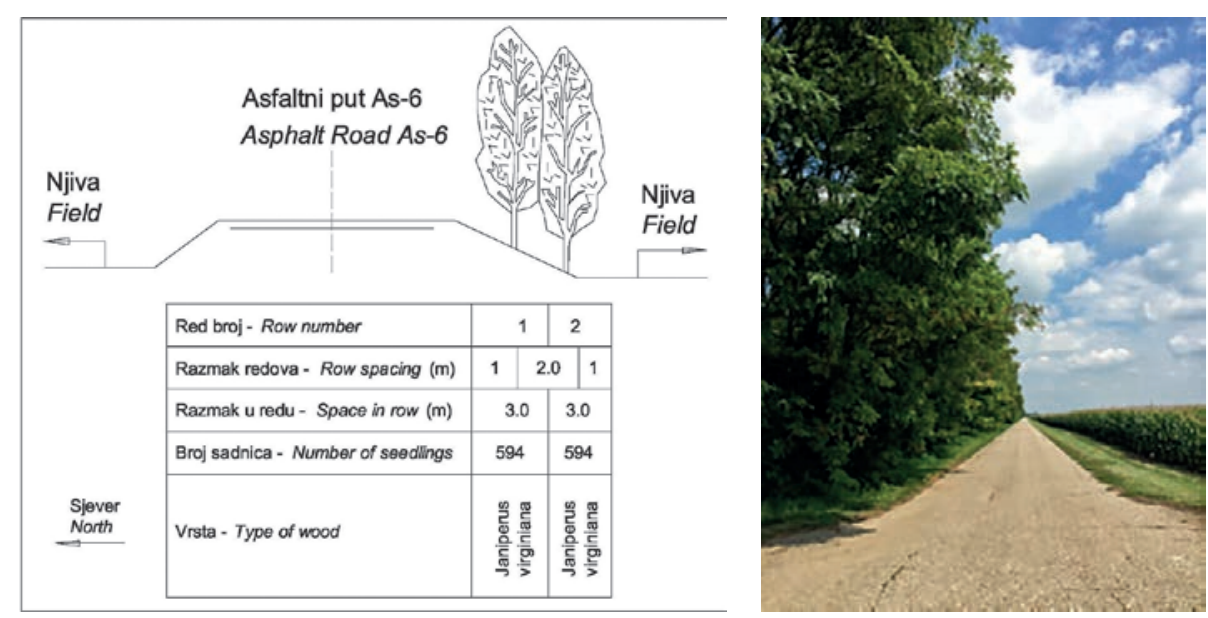

Slika 5. Zaštitni pojas kraj asfaltne ceste AS-6 - projektno rješenje (lijevo), stanje na terenu (desno)

Figure 5. Shelterbelt near asphalt road AS-6 - project solution (left) and the state on the terrain (right) 


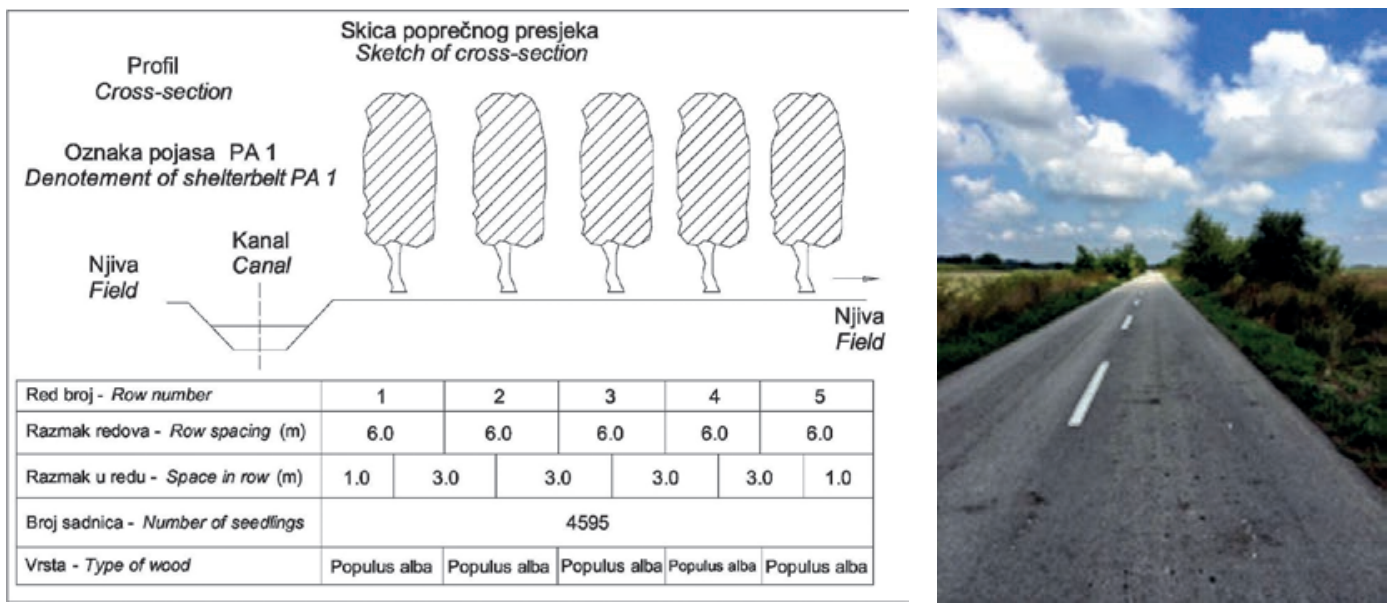

Slika 6. Poljozaštitni šumski pojas PA-1 - projektno rješenje (lijevo), stanje na terenu (desno)

Figure 6. Shelterbelt near asphalt road PA-1 - project solution (left) and the state on the terrain (right)

određuju na osnovi maksimalnih visina koje mogu dostići predložene vrste drveća (breza, žestika, javor, bagrem, crveni hrast, lužnjak, crni orah, topola, poljski jasen, sibirski brijest, joha, koprivić, lipa, sofora, dud, crni bor), što je uvjetovalo projektiranje pojaseva na udaljenosti 800 do 900 metara.

U nastavku teksta dan je primjer jednog šumskog pojasa u Općini Vršac.

\section{Poljozaštitni šumski pojas PA 1 - Shelterbelt PA 1}

Poljozaštitni šumski pojas PA 1 je projektiran u katastarskoj općini Pavliš. Ukupna dužina pojasa iznosi $5.514 \mathrm{~m}$.

Zaštitni pojas kraj asfaltnog puta AS-1 je projektiran sa sjeverne strane i sastoji se od pet redova topole s $4.595 \mathrm{sad}-$ nica (ŠFB, 2003) (Slika 6 - lijevo).

Na predmetnoj lokaciji je utvrđeno da poljozaštitni pojas ne postoji. Uočena su mjestimično pojedinačna stabla $\mathrm{i}$ sitno raslinje (Slika 6 - desno).

Nakon obilaska svih lokacija za novo projektirane šumske pojaseve, došlo se do zaključka da niti jedan nije realiziran. $\mathrm{Na}$ terenu se nalaze samo pojedinačna drveća, grmlje i sitno raslinje, koje je uslijed neredovitog održavanja, u vrlo lošem stanju.

\section{RASPRAVA I ZAKLJUČNA RAZMATRANJA DISCCUSSION AND FINAL CONSIDERATIONS}

U ovom radu su analizirani poljozaštitni šumski pojasevi, u svrhu utvrđivanja odstupanja između projektom definiranih pozicija i realiziranog stanja na terenu. Istraživanje je pokazalo da je područje Vojvodine, na osnovi svojih prirodnih karakteristika, ugroženo djelovanjem eolske erozije, a da su poljozaštitni šumski pojasevi, kao najbolji oblik borbe protiv štetnih utjecaja, u nedovoljnoj mjeri podignuti.

Tijekom istraživanja provedenog u Općini Bečej, došlo se do zaključka da je prvo izvedena komasacija, a nakon toga projektiranje poljozaštitnih šumskih pojaseva. S obzirom na to da je Projekt šumskih pojaseva za općinu Bečej iz 1984., a komasacija iz sedamdesetih godina, jasno je da ovi pojasevi nisu uzeti u obzir u postupku komasacije, što je rezultiralo realizacijom samo malog broja njih i to isključivo na društvenom zemljištu.

Osim toga, tijekom istraživanja došlo se i do zaključka da postojeći poljozaštitni šumski pojasevi u općini Bečej nisu učinkoviti, odnosno da visina stabala nije adekvatna. Naime, poznato je da je veličina utjecaja poljozaštitnog pojasa horizontalno proporcionalna njegovoj visini $(\mathrm{H})$. Na osnovi prikupljenih podataka iz brojne literature, utjecaj pojasa na redukciju brzine vjetra osjeća se ispred pojasa na udaljenosti 10-15 H, a iza pojasa na udaljenosti $40-50 \mathrm{H}$. To znači da pojas visine 15 metara (koliko je prosječna visina pojaseva u Općini Bečej), u najboljem slučaju, od vjetra štiti prostor na 750 metara od pojasa. Budući da dužina tabli koje bi postavljeni pojasevi trebali štititi, iznosi i preko 1500 metara, jasno je da je njihova učinkovitost nedostatna.

Slična situacija zatečena je i u Općini Sombor. Projekt šumskih pojaseva za ovu općinu rađen je 1989. godine, dok je komasacija rađena devedesetih godina 20. stoljeća. Glede te činjenice nejasno je zašto Projekt poljozaštitnih šumskih pojaseva nije realiziran paralelno, odnosno kroz postupak komasacije. Od projektiranih pojaseva realiziran je manji broj, i to onih koji su se nalazili na društvenom zemljištu.

Zatim je na kraju uslijedio primjer jedne novije komasacije koja je rađena u Općini Vršac, gdje su prvi puta u postupku komasacije izdvojene parcele baš za potrebe podizanja poljozaštitnih šumskih pojaseva.

Kod projektiranja i realizacije projekata poljozaštitnih šumskih pojaseva javlja se nekoliko problema, odnosno kontradiktornosti.

Prilikom projektiranja, odgovorni projektanti šumarske struke poštuju pravila projektiranja, pri čemu vode računa 
o visini stabala, obliku i širini pojasa, vrsti drveća, propusnoj moći itd., kao i smjernice dane u Prostornim planovima općina ili regija. Ovakvi projekti, koji su sa stručnog i znanstvenog gledišta izrađeni na vrhunskoj razini, „zaboravljaju“ problem osiguravanja zemljišta za njihovu realizaciju. Ovakvi projekti „ne prepoznaju“ pojam niti potencijal komasacije, odnosno kompatibilnost s projektom putne i kanalske mreže u komasaciji, kao jedine realno izvodljive opcije. Naime, poljozaštitni šumski pojasevi se projektiraju najčešće kao troredni ili petoredni, što iziskuje pojas minimalne širine od 15 metara. Postavlja se pitanje tko će i na koji način osigurati zemljište, koje po katastarskim općinama u kojima se realiziraju iznosi minimalno 100 hektara. Jedini ispravan i mogući način je osiguravanje zemljišta za zajedničke potrebe kroz komasaciju. Ovdje ne treba zaboraviti i sagledavanje opravdanosti investicije, gdje je u ovisnosti od vrste drveća za rast koji omogućuje optimalnu učinkovitost potrebno minimalno dvadesetak godina. Ako se uzme u obzir da broj sadnica prelazi znamenku od 100 tisuća po projektu, postavlja se i pitanje proizvodnih kapaciteta rasadnika i vremenski interval potreban za uzgoj sadnica.

S druge strane, javljaju se problemi kod osiguravanja zemljišta za zajedničke potrebe. Naime, u nekim realiziranim projektima, sudionici komasacije su s ciljem što manjeg koeficijenta odbitka tražili da poljoprivredni putevi budu uži za pola metra, što koeficijent mijenja na drugoj decimali. U projektima komasacije u općinama Žabari, Obrenovac i Aleksinac (Republika Srbija), išlo se tako daleko da su zborovi građana donosili odluke da koeficijent odbitka može biti maksimalno $1 \%$, što je u značajnoj mjeri otežalo izradu projekta putne i kanalske mreže (u ovakvim okolnostima, o realizaciji projekta poljozaštitnih šumskih pojaseva nema ni govora, jer potrebna površina za njihovu izgradnju višestruko povećava koeficijent). Na osnovi ovih činjenica postaje jasno zbog čega je za izgradnju poljozaštitnih šumskih pojaseva u najvećem broju slučajeva korišteno državno ili zemljište društvenih poljoprivrednih kombinata.

Uzimajući u obzir prethodno navedene činjenice, poučeni negativnim iskustvima ostalih općina u kojima su provođeni postupci komasacije i podizani poljozaštitni šumski pojasevi, čelnici Općine Vršac su po prvi puta u srbijanskoj praksi u projekt komasacije u katastarskim općinama Pavliš, Veliko Središte i Vršac uvrstili i projekte poljozaštitnih šumskih pojaseva. Ove projekte koji su obuhvatili područje cijelog Južnog Banata izradio je Šumarski fakultet iz Beograda, 2003. godine. Kao i kod ostalih prethodnih projekata $i$ kod ovog projekta (iako je izrađen na vrhunskoj razini) nije se vodilo računa o osiguravanju zemljišta za njegovu realizaciju, što je svakako najlakše kroz komasaciju.

Nakon nekoliko godina ukazala se potreba za komasacijom zemljišta u ovoj općini. Još u fazi izrade idejnog projekta, uvaženi su izrađeni projekti poljozaštitnih šumskih pojaseva i uvršteni u njegov sadržaj. Programom komasacije (Idejni projekt) za KO Pavliš koji je rađen 2010. godine za potrebe podizanja šumskih poljozaštitnih pojaseva predviđeno je 129,06 hektara s čak 109.233 sadnica. Ovo je pozitivan primjer komasacije, gdje se integralno razmatraju putna i kanalska mreža i poljozaštitni šumski pojasevi.

Unatoč saznanjima što šume znače za poljoprivredno zemljište, kao i za biljni i životinjski svijet i društvenu zajednicu u cjelini, ovakav potpuno ispravan i jedini moguć pristup izazvao je lavinu nezadovoljstva sudionika komasacije. Naime, problem je bio u velikoj površini zemljišta koju su svi sudionici proporcionalno trebali izdvojiti. Problem je riješen na taj način što je država iz svoje mase izdvojila veliku većinu zemljišta. Država je i u drugim općinama davala svoje zemljište za poljozaštitne šumske pojaseve, ali za razliku od tih slučajeva, ovdje su oni predviđeni na mjestima određenim na osnovi ozbiljnih istraživanja, odnosno na mjestima gdje će njihovi efekti biti najveći.

Problem druge vrste pojavio se nakon završetka komasacije i označavanja parcela za izgradnju poljozaštitnih šumskih pojaseva na terenu. Broj sadnica za podizanje šumskih pojaseva (oko 110.000 projektom predviđenih) nemoguće je osigurati u sljedećih 20 godina, iz rasadnika u Pančevu s kojim je sklopljen ugovor. Da li zbog ove činjenice ili iz nekog drugog razloga, ni nakon pet godina na projektiranim pozicijama nije posađeno niti jedno jedino stablo. Individualni poljoprivredni proizvođači spontano obrađuju zemljište rezervirano za podizanje poljozaštitnih šumskih pojaseva, jer ni u naznaci nema informacija kada će početi sadnja. Ovo je klasičan primjer uzurpacije državnog zemljišta u najgorem obliku, što naravno otvara druga pitanja i probleme.

Sveobuhvatno rješenje problema je izrada i realizacija Projekta poljozaštitnih šumskih pojaseva u procesu komasacije kroz izradu integralnog Projekta putne i kanalske mreže i poljozaštitnih šumskih pojaseva. Glede činjenice da se

Tablica 1. Pregledni prikaz komasacijskih projekata

Table 1. Overview of land consolidation projects

$\begin{array}{ccc}\begin{array}{c}\text { Ukupan broj Projekata } \\ \text { Total number of researched projects }\end{array} & \begin{array}{c}\text { Broj projekata komasacije u kojima je predviđena } \\ \text { uspostava poljozaštitnih šumskih pojaseva }\end{array} & \begin{array}{r}\text { Broj projekata komasacije u kojima su realizirani } \\ \text { poljozaštitni šumski pojasevi }\end{array} \\ >800 & <5 & \text { Number of projects where shelterbelts were foreseen projects where the shelterbelts were realized }\end{array}$


putna mreža uvijek realizira, prije izrade integralnog projekta potrebno je izvršiti realnu financijsku procjenu i u skladu sa tim uključiti kanalsku mrežu i poljozaštitne šumske pojaseve $\mathrm{u}$ integralni projekat.

$\mathrm{Na}$ osnovi izloženog može se zaključiti da je svijest o važnosti podizanja poljozaštitnih šumskih pojaseva u Republici Srbiji zaista niska. Pod utjecajem starih shvaćanja i u potrazi za najjednostavnijim izlazom iz takve situacije, još se i danas pojavljuju pojedinačni „glasovi“ da šume treba krčiti u korist poljoprivrede.

Nažalost, vrlo često je i komasacija sa svojim jednosektorskim pristupom poljoprivredi (glavni cilj je bio stvaranje velikih poljoprivrednih tabli, prilagođenih maksimalnom iskorištavanju moćne poljoprivredne mehanizacije) bila uzročnik nastanka erozivnih procesa.

Prilikom realizacije komasacije je činjena pogreška što su postojeći šumski nasadi, bilo da je riječ o linijskim ili nasadima druge vrste, a u cilju okrupnjavanja poljoprivrednih površina, bespoštedno uništavani. Na taj način stvorene su ekološke "mikro-pustinje", čime je osjetno pogoršan režim vjetrova. Ta pogreška je tipična za cijelo područje Vojvodine, ali isto tako i za ravničarske krajeve srednje Srbije. U tablici 1 je dan pregledni prikaz broja analiziranih projekata komasacije, broj projekata komasacije u kojima je planirana uspostava poljozaštitnih šumskih pojaseva i broj komasacijskih projekata u kojima su realizirani poljozaštitni šumski pojasevi.

Najbolji primjer je već spomenuta komasacija u općini Bečej, koja je započeta 1971. godine kada je stvoren kompleks društvenog gazdinstva od približno 10.000 ha, $\mathrm{s}$ tablama veličine oko 150 ha i dužine $1.500 \mathrm{~m}$. Već 1976. godine vjetar je odnio sjeme šećerne repe s površine od oko 500 ha i "premjestio" ga na površine koje su bile zasijane pšenicom, pri čemu je nastala šteta znatno veća od one koja je zahtijevala ponovnu sjetvu. To se ponavljalo svake 3-4 godine (Trifković i sur., 2013).

Neosporno je da su postojali brojni pokušaji da se osvijesti nužnost podizanja i očuvanja poljozaštitnih šumskih pojaseva, te je podizanje istih regulirano s više zakona i drugih pravilničkih propisa, od kojih neki nikada nisu realizirani. Iz razumljivih razloga, najviše propisa je doneseno u Vojvodini.

Na osnovi izloženog može se zaključiti da trenutna situacija glede projektiranja i podizanja poljozaštitnih šumskih pojaseva u Republici Srbiji nikako nije na zadovoljavajućoj razini. Međutim, ukoliko se na pravi način sagledaju opasnosti i štete od utjecaja vjetra, odnosno eolske erozije, samo po sebi se nameće da je projektiranje i podizanje poljozaštitnih šumskih pojaseva jedino rješenje koje bi osiguralo zaštitu poljoprivrednih površina, ali i donijelo koristi mnogim drugim granama i djelatnostima. Osim toga, posebnu pozornost treba posvetiti osiguravanju ne malih površina zemljišta za njihovo podizanje, što je svakako najlakše kroz realizaciju projekata komasacije. Odgovoran odnos prema poljoprivrednom zemljištu sa gledišta održivog razvoja, također nameće imperativ poduzimanja svih mjera koje mogu smanjiti njegovu devastaciju uz povećanje ukupnih pozitivnih učinaka, pri čemu poljozaštitni šumski pojasevi imaju nezamjenljivu ulogu. Integralno planiranje komasacije podrazumijeva, između ostalog, i uključivanje eksperata iz oblasti šumarske struke u proces planiranja, kako bi se povećali ukupni učinci komasacije.

\section{LITERATURA}

- Brandle, J. R., B. B. Johnson, T. Akeson, 1992: Field windbreaks: Are they economical?. Journal of Production Agriculture, 5(3): 393-398.

- Caborn, J.M., 1957: Shelterbelts and Microclimate, Department of Forestry, Edinburgh University, https://www.fs.usda.gov/nac/ documents/shelterbelts/sectionA.pdf (pristupljeno: 16.02.2019)

- Domac, J., 2000: Prvi rezultati međunarodnog projekta "Socio - economic aspects of bioenergy systems". Šumarski list, 124(78): 413-419.

- Domac, J., S. Risović, V. Šegon, T. Pentek, B. Šafran, I. Papa, 2015: Može li biomasa pokrenuti energijsku tranziciju u Hrvatskoj i Jugoistočnoj Evropi?. Šumarski list, 139(11-12): 561-569.

- Dožić, S., 2006: Poljozaštitni šumski pojasevi - vanšumsko zelenilo. U: Savetovanje - Pošumljavanje u cilju realizacije prostornog plana i razvoja poljoprivrede, šumarstva i vodoprivrede Republike Srbije, 34-45., Novi Sad

- Drekić, M., S. Orlović, Z. Galić, S. Stojnić, S. Pekeč, V. Vasić, A. Pilipović, 2016: Rezultati procene uticaja aerozagađenja na stanje šuma u Vojvodini, Topola, (197-198), 81-90.

- Drvodelić, D., M. Oršanić, 2016: Procjena vitaliteta svježeg i preležalog sjemena poljskog jasena (FraxinusangustifoliaVahl). Šumarski list, 140(11-12): 539-547.

- Građevinski fakultet Beograd (GFB), 2010: Program komasacije KO Pavliš (Opština Vršac), Vršac

- Hendricks A., A. Lisec, 2014: Land consolidation for large scale infrastructure projects in Germany. Geodetski vestnik, 58(1): 46-68.

- Jones, H. R., R. A. Sudmeyer, 2002: Economic assessment of windbreaks on the south-eastern coast of Western Australia. Australian Journal of Experimental Agriculture, 42(6): 751-761.

- Krpina, V., Ž. Španjol, A. Jazbec, 2014: Uloga šuma i šumarstva u turizmu i zaštiti prirode na području zadarske županije. Šumarski list, 138(5-6): 271-281.

- Letić, Lj., R. Savić, 2006: Intenzitet procesa eolske erozije na Subotičko-Horgoškoj peščari. U: Savetovanje-Pošumljavanje u cilju realizacije prostornog plana i razvoja poljoprivrede, šumarstva i vodoprivrede Republike Srbije, 25-34., Novi Sad

- Lukić, S., 2005: Uticaj standardnih tipova šumskih pojaseva i standardnih poljoprivrednih kultura na na brzinu vetra. Magistarski rad, str. 42, Šumarski fakultet, Beograd

- Marinković, G., M. Trifković, Ž. Nestorović, 2013: Mogućnost rekomasacije u Srbiji na primeru Opštine Sombor. Zbornik radova Građevinskog fakulteta Subotica, (22): 199-208.

- Martinić, I., 2004: Šumarska struka u svjetlu uspostave ekološke mreže Republike Hrvatske. Šumarski list, 128(3-4): 163-171. 
- Pearce, D., E. Barbier, A. Markandya, 1990: Sustainable development, Economic and Environment in the Third World, Earthscan Ltd, Dunstan House, 14a St Cross Street, London, UK.

- Rempel, J.C., S.N. Kulshreshtha, B.Y. Amichev, K.C. van Rees, 2016: Costs and benefits of shelterbelts: A review of producers' perceptions and mind map analyses for Saskatchewan, Canada. Canadian Journal of Soil Science, 97(3): 341-352.

- Strategija poljoprivrede i ruralnog razvoja Republike Srbije za period 2014-2024. godine. („Službeni glasnik Republike Srbije“. br. $85 / 14)$

- Strategija razvoja šumarstva Republike Srbije, („Službeni glasnik Republike Srbije“. br. 59/06)

- Šumarski fakultet Beograd (ŠFB), 1984: Projekat šumskih zaštitnih pojaseva na području S.O. Bečej

- Šumarski fakultet Beograd (ŠFB), 1989: Projekat šumskih vetrozaštitnih pojaseva za S.O. Sombor

- Šumarski fakultet Beograd (ŠFB), 2003: Projekat šumskih vetrozaštitnih pojaseva za S.O. Vršac
- Trifković, M., G. Marinković, B. Ilić, G. Pejičić, J. Lazić, 2016: Land consolidation and irrigation, case study Municipality of Velika Plana. Archives for Technical Sciences, 14 (1):35-45.

- Trifković, M., T. Ninkov, G. Marinković, 2013: Komasacija. FTN Izdavaštvo, str. 345, Novi Sad

- Zakon o komasaciji i arondaciji Socijalističke Autonomne Pokrajine Vojvodine. („Službeni list SAPV“. br. 16/78, 22/78 i 32/78)

- Zakon o komasaciji („Narodne novine Republike Hrvatske“, br. 10/79, 21/84 i 5/87)

- Zakon o poljoprivrednom zemljištu („Službeni glasnik Republike Srbije“. br. 62/06, 65/08, 41/09, 112/15 i 80/17)

- Zakon o poljoprivredi i ruralnom razvoju („Službeni glasnik Republike Srbije“. br. 41/09, 10/13 i 101/16)

- Zakon o šumama Republike Srbije („Službeni glasnik Republike Srbije“. br. 30/10, 93/12 i 89/15)

- http://www.vojvodinasume.rs/sume/procena-optimalne-sumovitosti-u-vojvodini (pristupljeno: 05.12.2018.)

\section{SUMMARY:}

The forests as a necessary condition for human civilization existence also are of great ecological and economic importance. This fact is often neglected in practice despite the fact on wide spread scientific knowledge about it. The authors noticed that practice and made research about shelterbelts realization in the numerous cases of theoretical researches as well as in projects of land consolidation projects in Serbia (mostly of them provided in Autonomous Province of Vojvodina as a region where agricultural land dominates). The benefits of shelterbelts are well known from scientific literature and practice for agricultural land protection, but the realization of them in concrete projects are connected with a lot of obstacles. In this paper more than the author ivestigated the projects of land consolidation from the aspect of the chances for building shelterbelts and their realization in practice. The research provided on more than eight hunderd projects of land consolidation has shown that only in a few of them the shelterbelts were forseen and no one of them was realized as designed. The reasons are mostly connected with the resistance of participants in land consolidation to give up of their land for shelterbelts building, with lack of capacities for seedlings providing and with the insufficient attention paid to this issue in legal regulation.

In this paper the results of analysis of shelterbelts in the process of land consolidation are shown. Research encompassed three different and distinguished projects of land consolidation in Autonomous Province of Vojvodina - The Republic of Serbia, through which realization was required to provide the projects of shelterbelts. Bearing in mind that chosen projects are spread in different geographical areas of research fields, the conclusions obtained in this paper could be considered as representative for Vojvodina. The Vojvodina is especcialy interesting for research because this region is lacking with forest. To reach the standards of 0.16 hecteares per citizen the woodlands in Vojvodina shall be increased from actual value of 193,621 hectares to the values of 308,045 hectares. Bearing in mind that importance of agricultural land and its preservation in the future from the aspect of sustainable development the land consolidation projects are the best chance for reaching before mention goal of increasing woodlands in Vojvodina. The study has shown that chance for increasing forest area in Vojvodina was not utilized, i.e. that projects of shelterbelts were not taken into consideration, and even if they were, the considered area was never brought to the designed goals. The visualization of project solutions and the actual implementation of the shelterbelts in the considered municipalities is shown in Figures 1-6. Overview of the number of analyzed projects of land consolidation, the number of land consolidation projects where was planned the establishment of shelterbelts and the number of land consolidation projects where are realized shelterbelts is given in Table 1. 